\title{
Experiences and Impact of COVID-19 Pandemic on Students and Academics in Health Care Education in Universiti Brunei Darussalam
}

Fazean Idris ( $\sim$ fazean.idris@ubd.edu.bn )

Universiti Brunei Darussalam

Ihsan Zulkipli

Universiti Brunei Darussalam

Khadizah Abdul Mumin

Universiti Brunei Darussalam

Rohaiza Ahmad

Universiti Brunei Darussalam

Shahid Mitha

Universiti Brunei Darussalam

Hanif Abdul Rahman

Universiti Brunei Darussalam

Rajan Rajabalaya

Universiti Brunei Darussalam

Sheba David

Universiti Brunei Darussalam

Lin Naing

Universiti Brunei Darussalam

\section{Research Article}

Keywords: Online education, experiences and impact, COVID-19, pandemic, students, academics, university

Posted Date: July 27th, 2021

DOI: https://doi.org/10.21203/rs.3.rs-713663/v1

License: (c) (1) This work is licensed under a Creative Commons Attribution 4.0 International License.

Read Full License 


\section{Abstract}

Background: In keeping with nation-wide efforts to contain the spread of COVID-19, Universiti Brunei Darussalam (UBD) made the move towards online teaching to ensure students continue to receive their education while minimizing the risks of exposure and community spread of COVID-19. We investigated teaching and learning experiences, physical and mental health of undergraduate students and academic staff during the COVID-19 pandemic.

Methods: We conducted a cross-sectional study on undergraduate students and academic staff in a health science faculty using a self-developed pretested questionnaire through anonymous online data collection method.

Results: 56 academics (100\% response rate) and 279 students (83.3\% response rate) participated. The positive experiences as reported by students include: becoming independent (72.8\%), adapting to online learning $(67.4 \%)$ and sudden changes $(62.0 \%)$, learning to manage scheduling (58.8\%), and being selfmotivated (57.7\%); while academics' positive experiences included new teaching techniques $(50.0 \%)$, flexible schedules (50.0\%), remote teaching (48.2\%) and improved teaching tools (46.4\%). Students reported negative experiences as being distracted at home (72.0\%), feeling of uncertainty with regards to examinations $(66.7 \%)$, and getting a slow response from lecturers $(55.6 \%)$. With regards to health, both students and academics reported stress, anxiety, loneliness, back problems, and eye strain.

Conclusion: In this challenging period towards an abrupt shift to online teaching, students and academic staff of UBD identified both positive and negative experiences including the impact on their physical and mental health. Our findings are important to provide the evidence for online pedagogical benefits and can serve to promote the enhancement and adaptation of digital technology in education. Our findings also aim to promote the importance of addressing physical and mental health issues of the university community's well-being through provision of emotional and mental health support and appropriate programs.

\section{Introduction}

Brunei Darussalam, a country with a population of 459 400, recorded its first imported case of COVID-19 on 9th March 2020 [1]. The government of Brunei Darussalam worked swiftly to prevent the spread of the virus, including closing of schools and allowing parts of the working population, including academics, to work from home. As the pandemic spread worldwide and the country saw a surge of positive cases, strict isolation measures were put in place to protect individuals from exposure to the virus while curbing the risk of community spread. In keeping with nation-wide efforts to contain the spread of the disease, Universiti Brunei Darussalam (UBD) moved its teaching and learning online for the duration of the ongoing semester to ensure that university students continued to receive their education [2]. Academics conducted teaching and assessments using multiple online learning platforms, such as Canvas, Microsoft Teams, Google Meet, Skype and Zoom while practical sessions were held with social and 
physical distancing, proper cleanliness, mask usage and through cohorting in a staggered approach following the Ministry of Health guidelines [3]. Soon, the advantages of online learning systems became apparent. Lectures and problem-based learning (PBL) could be continued using online learning management system, teleconferencing applications and devices. Teaching and learning activities in UBD continued undisrupted during the pandemic.

Research reporting the impact of COVID-19 on student education and welfare has observed that academic disruption can affect the university's teaching delivery and result in psychosocial consequences for its university community. Students are often faced with increased anxiety during the pandemic, which may lead to decreased motivation towards studying [4] and this can be correlated with increased concerns on academic, social and economic well-being [5]. College students can struggle with loneliness and isolation not only because of disconnections from friends, but the abrupt disruption of the semester can cause cessation in their research projects and internships, leading to uncertainty in graduation and job market availability [6]. Students' research output can also be markedly reduced due to the abandonment of hospital or clinical based research work [7].

In this study, we investigated teaching, learning and assessment experiences as well as explored physical and mental impact of university students and academics during the COVID-19 pandemic. Our findings may be important in identifying useful strategies and innovative approaches to support online teaching and learning, potentially support students' educational progress, as well as identify coping strategies in combating negative implications of the pandemic on the university community's physical and mental health.

\section{Materials And Methods}

\section{Study Design and Population}

A cross-sectional study was conducted from 2nd April to 12th April 2020 amongst academics involved in undergraduate teaching and undergraduate students of the Bachelor of Health Science programmes (majoring in Medicine, Dentistry, Pharmacy, Biomedical Sciences, Nursing \& Midwifery) from the Pengiran Anak Puteri Rashidah Sa'adatul Bolkiah Institute of Health Sciences (PAPRSB-IHS), Universiti Brunei Darussalam. The undergraduate students were those who had registered for at least one module during the January to May 2020 semester. Students in community outreach, internships or study-abroad programmes were excluded from the study. All 56 academics and 299 undergraduate students of the eligible population were invited to participate in the study without sampling.

\section{Data Collection}

A pretested questionnaire was set up on the Qualtrics online platform subscribed by the University to collect the data. A uniform link was created and sent to the group email of all eligible academics and students (staff.ihs@ubd.edu.bn and student.ihs@ubd.edu.bn) to ensure anonymous data collection. Clicking on the link led to the page containing the participant information sheet, which asked for their 
consent to participate in the study. Participants were reminded about the study twice via mass email after 3 and 7 days.

\section{Research Instrument}

The questionnaire was designed after three mini-workshop sessions, two of which were held with students and one with academics, from each health science major (namely Medicine, Dentistry, Pharmacy, Biomedical Sciences, Nursing \& Midwifery). Questionnaire was designed based on the discussions generated from the workshop participants as well as input from the research team. The questionnaire was pretested among academics and students before it was finalized, and included questions relating to their teaching and learning experiences as well as their perceived physical and mental health during the COVID-19 pandemic. For academics, an additional section on their opinions of positive and negative effects of assessments was included in the questionnaire.

\section{Data analysis}

Data was downloaded into Microsoft Excel from the Qualtrics platform and was processed for labeling categories and missing data. Data were described using descriptive statistics as appropriate, and group comparisons were made using chi-square test for categorical variables and independent $t$ test or one-way ANOVA for numerical variables. R (version 4.0.2) and RStudio (version 1.3.1056) for Windows were used for all analyses.

\section{Ethical Consideration}

The project was approved by PAPRSB-IHS Research Ethics Committee and University Research Ethics Committee of Universiti Brunei Darussalam (UBD/OAVCR/UREC/Apr2020-01).

\section{Results}

\section{Demographic Characteristics of Participants}

A total of 279 health science undergraduate students (83.3\% response rate) and 56 academic staff (100\% response rate) participated in this study. Amongst the students, 103 (36.9\%) were from programmes of nursing, 60 (21.5\%) from medicine, 50 (17.9\%) from biomedical sciences, 36 (12.9\%) from pharmacy and $30(10.8 \%)$ from dentistry. $72.6 \%$ of students were female with majority of them in Year 1 (38.9\%), followed by Year 2 (31.3\%), Year 3 (18.4\%) and Year 4 (11.5\%). Over 95\% of students reported having internet access. 16 (28.6\%) of the academics were from programmes of nursing, $12(21.4 \%)$ from biomedical sciences, 8 (14.3\%) from medicine, 4 (7.1\%) from pharmacy and 2 (3.6\%) from dentistry. Majority (66.7\%) of academics were female, local Bruneians (78.6\%), aged between 41 to 50 years old (43.9\%) and had more than 10 years of academic experience (51.2\%).

\section{Teaching, Learning and Assessment Experiences}


Table 1 illustrates students' positive and negative experiences of learning during COVID-19 pandemic. A majority reported that they became independent (72.8\%), adapted to online learning (67.4\%) and sudden changes (62.0\%), learnt to set and keep a schedule (58.8\%), and became self-motivated (57.7\%). However, a majority also reported being distracted when studying from home $(72.0 \%)$ and was less certain about assessment and examination (66.7\%). More than half of the students reported having a lack of spontaneous interaction with lecturers (55.6\%), distracted during live video lectures by noisy background $(55.6 \%)$ and challenged to do group work (51.3\%). 
Table 1

Positive and negative learning experiences by students $(n=279)$ during COVID-19 pandemic

\begin{tabular}{|c|c|c|c|c|c|c|c|}
\hline Learning experience & $\begin{array}{l}\text { Total } \\
(n= \\
279)\end{array}$ & $\begin{array}{l}\text { Biomed. } \\
(n=50)\end{array}$ & $\begin{array}{l}\text { Dentistry } \\
(n=30)\end{array}$ & $\begin{array}{l}\text { Medicine } \\
(n=60)\end{array}$ & $\begin{array}{l}\text { N\&MW } \\
(n= \\
103)\end{array}$ & $\begin{array}{l}\text { Pharmacy } \\
(n=36)\end{array}$ & $\begin{array}{l}p- \\
\text { value }\end{array}$ \\
\hline Positive & $\mathrm{n}(\%)$ & n (\%) & n (\%) & n (\%) & n (\%) & n (\%) & \\
\hline Be independent & $\begin{array}{l}203 \\
(72.8)\end{array}$ & $\begin{array}{l}39 \\
(78.0)\end{array}$ & $\begin{array}{l}25 \\
(83.3)\end{array}$ & $40(66.7)$ & $\begin{array}{l}77 \\
(74.8)\end{array}$ & $22(61.1)$ & 0.087 \\
\hline Adapt online learning & $\begin{array}{l}188 \\
(67.4)\end{array}$ & $\begin{array}{l}35 \\
(70.0)\end{array}$ & $\begin{array}{l}25 \\
(83.3)\end{array}$ & $40(66.7)$ & $\begin{array}{l}70 \\
(68.0)\end{array}$ & $18(50.0)$ & 0.057 \\
\hline $\begin{array}{l}\text { Adapt to sudden } \\
\text { change }\end{array}$ & $\begin{array}{l}173 \\
(62.0)\end{array}$ & $\begin{array}{l}29 \\
(58.0)\end{array}$ & $\begin{array}{l}23 \\
(76.7)\end{array}$ & $40(66.7)$ & $\begin{array}{l}60 \\
(58.3)\end{array}$ & $20(55.6)$ & 0.374 \\
\hline $\begin{array}{l}\text { Set and keep } \\
\text { schedule }\end{array}$ & $\begin{array}{l}164 \\
(58.8)\end{array}$ & $\begin{array}{l}27 \\
(54.0)\end{array}$ & $\begin{array}{l}18 \\
(60.0)\end{array}$ & $32(53.3)$ & $\begin{array}{l}69 \\
(67.0)\end{array}$ & $18(50.0)$ & 0.366 \\
\hline Be self-motivated & $\begin{array}{l}161 \\
(57.7)\end{array}$ & $\begin{array}{l}30 \\
(60.0)\end{array}$ & $\begin{array}{l}20 \\
(66.7)\end{array}$ & $32(53.3)$ & $\begin{array}{l}59 \\
(57.3)\end{array}$ & $20(55.6)$ & 0.658 \\
\hline More attentive online & $\begin{array}{l}138 \\
(49.5)\end{array}$ & $\begin{array}{l}22 \\
(44.0)\end{array}$ & $\begin{array}{l}16 \\
(53.3)\end{array}$ & $22(36.7)$ & $\begin{array}{l}53 \\
(51.5)\end{array}$ & $17(47.2)$ & 0.420 \\
\hline $\begin{array}{l}\text { Environmentally } \\
\text { friendly }\end{array}$ & $\begin{array}{l}131 \\
(47.0)\end{array}$ & $\begin{array}{l}28 \\
(56.0)\end{array}$ & $\begin{array}{l}13 \\
(43.3)\end{array}$ & $17(28.3)$ & $\begin{array}{l}59 \\
(57.3)\end{array}$ & $14(38.9)$ & 0.002 \\
\hline $\begin{array}{l}\text { Replay recorded } \\
\text { lectures }\end{array}$ & $\begin{array}{l}128 \\
(45.9)\end{array}$ & $\begin{array}{l}29 \\
(58.0)\end{array}$ & $9(30.0)$ & $23(38.3)$ & $\begin{array}{l}55 \\
(53.4)\end{array}$ & $12(33.3)$ & 0.007 \\
\hline Lecturers more IA & $\begin{array}{l}79 \\
(28.3)\end{array}$ & $\begin{array}{l}15 \\
(30.0)\end{array}$ & $7(23.3)$ & $8(13.3)$ & $\begin{array}{l}39 \\
(37.9)\end{array}$ & $10(27.8)$ & 0.018 \\
\hline
\end{tabular}

\section{Negative}

\begin{tabular}{|c|c|c|c|c|c|c|c|}
\hline $\begin{array}{l}\text { Distracted when } \\
\text { working from home }\end{array}$ & $\begin{array}{l}201 \\
(72.0)\end{array}$ & $\begin{array}{l}34 \\
(68.0)\end{array}$ & $\begin{array}{l}28 \\
(93.3)\end{array}$ & $40(66.7)$ & $\begin{array}{l}74 \\
(71.8)\end{array}$ & 25 (69.4) & 0.103 \\
\hline $\begin{array}{l}\text { Less certain about } \\
\text { assessment and } \\
\text { exam }\end{array}$ & $\begin{array}{l}186 \\
(66.7)\end{array}$ & $\begin{array}{l}34 \\
(68.0)\end{array}$ & $\begin{array}{l}27 \\
(90.0)\end{array}$ & 41 (68.3) & $\begin{array}{l}62 \\
(60.2)\end{array}$ & $22(61.1)$ & 0.030 \\
\hline
\end{tabular}

$\begin{array}{llllllll}\begin{array}{l}\text { Live lectures } \\ \text { distracted or noisy } \\ \text { background }\end{array} & \begin{array}{l}155 \\ (55.6)\end{array} & \begin{array}{l}28 \\ (56.0)\end{array} & \begin{array}{l}22 \\ (73.3)\end{array} & 26(43.3) & 63 & 16(44.4) & 0.031 \\ \begin{array}{l}\text { No spontaneous } \\ \text { interaction }\end{array} & \begin{array}{l}155 \\ (55.6)\end{array} & \begin{array}{l}27 \\ (54.0)\end{array} & \begin{array}{l}23 \\ (76.7)\end{array} & 28(46.7) & \begin{array}{l}61 \\ (59.2)\end{array} & 16(44.4) & 0.052 \\ & & & & & \end{array}$

\footnotetext{
a Chi-square test for independence; Biomed.=Biomedical Sciences; N\&MW = Nursing and Midwifery; $\mathrm{IA}=$ Interaction
} 


\begin{tabular}{|c|c|c|c|c|c|c|c|}
\hline Learning experience & $\begin{array}{l}\text { Total } \\
(n= \\
279)\end{array}$ & $\begin{array}{l}\text { Biomed. } \\
(n=50)\end{array}$ & $\begin{array}{l}\text { Dentistry } \\
(n=30)\end{array}$ & $\begin{array}{l}\text { Medicine } \\
(n=60)\end{array}$ & $\begin{array}{l}\text { N\&MW } \\
(n= \\
103)\end{array}$ & $\begin{array}{l}\text { Pharmacy } \\
(n=36)\end{array}$ & value \\
\hline $\begin{array}{l}\text { Group work become } \\
\text { challenging }\end{array}$ & $\begin{array}{l}143 \\
(51.3)\end{array}$ & $\begin{array}{l}23 \\
(46.0)\end{array}$ & $\begin{array}{l}18 \\
(60.0)\end{array}$ & $22(36.7)$ & $\begin{array}{l}61 \\
(59.2)\end{array}$ & $19(52.8)$ & 0.068 \\
\hline $\begin{array}{l}\text { Missed live lectures } \\
\text { frequently }\end{array}$ & $\begin{array}{l}89 \\
(31.9)\end{array}$ & $\begin{array}{l}13 \\
(26.0)\end{array}$ & $\begin{array}{l}12 \\
(40.0)\end{array}$ & $9(15.0)$ & $\begin{array}{l}46 \\
(44.7)\end{array}$ & $9(25.0)$ & 0.002 \\
\hline $\begin{array}{l}\text { Lecturers less prompt } \\
\text { to answer online } \\
\text { questions }\end{array}$ & $\begin{array}{l}80 \\
(28.7)\end{array}$ & $\begin{array}{l}11 \\
(22.0)\end{array}$ & $9(30.0)$ & $14(23.3)$ & $\begin{array}{l}41 \\
(39.8)\end{array}$ & $15(41.7)$ & 0.027 \\
\hline \multicolumn{8}{|c|}{$\begin{array}{l}\text { a Chi-square test for independence; Biomed.=Biomedical Sciences; N\&MW = Nursing and Midwifery; } \\
\text { IA = Interaction }\end{array}$} \\
\hline
\end{tabular}

Figure 1 illustrates academics' positive and negative experiences of teaching and research during the study. A majority of academics reported their positive experiences as 'learning new teaching techniques' $(50 \%)$ and 'becoming creative and innovative' (50.0\%). However, they felt that students' lab skills may have been compromised (44.6\%) and could not control students' attendances $(42.9 \%)$. They were also uncertain about students' learning achievements (41.1\%).

Figure 2 illustrates academics' positive and negative effects of designing assessments during the study. $50 \%$ reported that they were able to explore all options while becoming creative and innovative, but on the other hand found that it was difficult to maintain appropriate assessments $(41.1 \%)$ and to ensure a fair assessment (37.5\%).

\section{Physical and Mental Health Experiences of Students and Academics}

Table 2 shows the experiences of physical and mental health of students in this study. In terms of physical health, students reported 'missing eating outside' (68.8\%) and 'no extracurricular activities' (64.9\%). They also reported more back problems (58.4\%) and eye strain/ dry eyes (51.3\%). In terms of mental health, increased stress was reported (64.9\%), followed by anxiety (49.5\%), loneliness (47.0\%) and depression (24.1\%). However, they also reported more time for self-reflection (54.8\%). 
Table 2

Physical and mental health experiences of students $(n=279)$

\begin{tabular}{llllllll}
$\begin{array}{l}\text { Reported Health } \\
\text { Experiences }\end{array}$ & Total & Biomed. & Dentistry & Medicine & N\&MW & Pharmacy & $p$ - \\
& $\begin{array}{l}(n= \\
279)\end{array}$ & $(n=50)$ & $(n=30)$ & $(n=60)$ & $\begin{array}{l}(n= \\
103)\end{array}$ & $(n=36)$ & value $^{\text {a }}$ \\
\cline { 2 - 6 } & $\mathrm{n}(\%)$ & $\mathrm{n}(\%)$ & $\mathrm{n}(\%)$ & $\mathrm{n}(\%)$ & $\mathrm{n}(\%)$ & $\mathrm{n}(\%)$ &
\end{tabular}

\section{Physical Health}

\begin{tabular}{|c|c|c|c|c|c|c|c|}
\hline Miss eating outside & $\begin{array}{l}192 \\
(68.8)\end{array}$ & $\begin{array}{l}32 \\
(64.0)\end{array}$ & $\begin{array}{l}25 \\
(83.3)\end{array}$ & $41(68.3)$ & $\begin{array}{l}70 \\
(68.0)\end{array}$ & $24(66.7)$ & 0.580 \\
\hline No more ECAs & $\begin{array}{l}181 \\
(64.9)\end{array}$ & $\begin{array}{l}34 \\
(68.0)\end{array}$ & $\begin{array}{l}24 \\
(80.0)\end{array}$ & $36(60.0)$ & $\begin{array}{l}64 \\
(62.1)\end{array}$ & $23(63.9)$ & 0.234 \\
\hline $\begin{array}{l}\text { Home cooked } \\
\text { meals }\end{array}$ & $\begin{array}{l}169 \\
(60.6)\end{array}$ & $\begin{array}{l}35 \\
(70.0)\end{array}$ & $\begin{array}{l}23 \\
(76.7)\end{array}$ & $29(48.3)$ & $\begin{array}{l}63 \\
(61.2)\end{array}$ & 19 (52.8) & 0.016 \\
\hline Back problems & $\begin{array}{l}163 \\
(58.4)\end{array}$ & $\begin{array}{l}30 \\
(60.0)\end{array}$ & $\begin{array}{l}22 \\
(73.3)\end{array}$ & $29(48.3)$ & $\begin{array}{l}61 \\
(59.2)\end{array}$ & $21(58.3)$ & 0.190 \\
\hline Eye strain/dry eyes & $\begin{array}{l}143 \\
(51.3)\end{array}$ & $\begin{array}{l}24 \\
(48.0)\end{array}$ & $\begin{array}{l}22 \\
(73.3)\end{array}$ & $25(41.7)$ & $\begin{array}{l}56 \\
(54.4)\end{array}$ & $16(44.4)$ & 0.066 \\
\hline $\begin{array}{l}\text { Less time for } \\
\text { exercise }\end{array}$ & $\begin{array}{l}125 \\
(44.8)\end{array}$ & $\begin{array}{l}17 \\
(34.0)\end{array}$ & $\begin{array}{l}15 \\
(50.0)\end{array}$ & $22(36.7)$ & $\begin{array}{l}56 \\
(54.4)\end{array}$ & 15 (41.7) & 0.144 \\
\hline Gained weight & $\begin{array}{l}116 \\
(41.6)\end{array}$ & $\begin{array}{l}18 \\
(36.0)\end{array}$ & $\begin{array}{l}13 \\
(43.3)\end{array}$ & $18(30.0)$ & $\begin{array}{l}52 \\
(50.5)\end{array}$ & $15(41.7)$ & 0.150 \\
\hline $\begin{array}{l}\text { More exercise at } \\
\text { home }\end{array}$ & $\begin{array}{l}100 \\
(35.8)\end{array}$ & $\begin{array}{l}23 \\
(46.0)\end{array}$ & $\begin{array}{l}15 \\
(50.0)\end{array}$ & 19 (31.7) & $\begin{array}{l}29 \\
(28.2)\end{array}$ & $14(38.9)$ & 0.043 \\
\hline
\end{tabular}

Mental health

\begin{tabular}{|c|c|c|c|c|c|c|c|}
\hline More stressed & $\begin{array}{l}181 \\
(64.9)\end{array}$ & $\begin{array}{l}37 \\
(74.0)\end{array}$ & $\begin{array}{l}19 \\
(63.3)\end{array}$ & $30(50.0)$ & $\begin{array}{l}74 \\
(71.8)\end{array}$ & $22(61.1)$ & 0.010 \\
\hline Self-reflection & $\begin{array}{l}153 \\
(54.8)\end{array}$ & $\begin{array}{l}28 \\
(56.0)\end{array}$ & $\begin{array}{l}22 \\
(73.3)\end{array}$ & $34(56.7)$ & $\begin{array}{l}51 \\
(49.5)\end{array}$ & $18(50.0)$ & 0.187 \\
\hline Anxiety problem & $\begin{array}{l}138 \\
(49.5)\end{array}$ & $\begin{array}{l}25 \\
(50.0)\end{array}$ & $\begin{array}{l}12 \\
(40.0)\end{array}$ & $25(41.7)$ & $\begin{array}{l}61 \\
(59.2)\end{array}$ & 15 (41.7) & 0.115 \\
\hline Felt lonely & $\begin{array}{l}131 \\
(47.0)\end{array}$ & $\begin{array}{l}25 \\
(50.0)\end{array}$ & $\begin{array}{l}18 \\
(60.0)\end{array}$ & 35 (58.3) & $\begin{array}{l}41 \\
(39.8)\end{array}$ & 12 (33.3) & 0.033 \\
\hline More relaxed & $\begin{array}{l}127 \\
(45.5)\end{array}$ & $\begin{array}{l}21 \\
(42.0)\end{array}$ & $\begin{array}{l}19 \\
(63.3)\end{array}$ & $28(46.7)$ & $\begin{array}{l}43 \\
(41.7)\end{array}$ & $16(44.4)$ & 0.357 \\
\hline More depressed & $\begin{array}{l}95 \\
(34.1)\end{array}$ & $\begin{array}{l}13 \\
(26.0)\end{array}$ & $\begin{array}{l}11 \\
(36.7)\end{array}$ & $18(30.0)$ & $\begin{array}{l}38 \\
(36.9)\end{array}$ & $15(41.7)$ & 0.604 \\
\hline
\end{tabular}

a Chi-square test for independence; Biomed.=Biomedical Sciences; N\&MW = Nursing and Midwifery 
Meanwhile, academics reported more time for exercise (51.8\%), despite having more screen time (50.0\%) and computer-related physical stress (44.6\%) (Fig. 3a). Although academics reported a closer relationship with family (44.6\%), they also felt more stressed (due to deadlines, unexpected disruptions, higher workloads) (44.6\%) as well as concerns related to work, family and self (39.3\%) (Fig. 3b).

\section{Discussion}

Students' and Academics' Experiences from Online Education and Assessments

Our study provides favorable evidence of online learning among students during the pandemic with a majority reporting that they became independent, adapted to online learning and became more selfmotivated, reinforcing that online pedagogy certainly has its benefits in encouraging students to work independently and enhance their self-efficacy. Evidence has suggested that students who are independent learners, work to higher standards, use a range of strategies in their learning, are competent in their problem-solving skills, more motivated and have higher self-esteem [8]. In addition, such pedagogical method can enhance students to become self-directed learners, which is an important competency required to be a life-long learner, particularly in the field of health care [9]. On the contrary, the downside reported by the students in our study was distractions when studying from home, such as a noisy background during live video lectures. This adds to the current knowledge on the dilemma of home learning. Environmental factors at home may be inevitable due to conflict in tasks with either daily household chores and family or personal commitments at home. In addition, students' family or household members may not have appreciated the privacy and quietness that students need to focus when receiving online education. Students may also be challenged by their academic roles as students, which are in conflict with their roles as family members to perform assigned family tasks and duties during the pandemic. Another negative experience identified by students was the lack of spontaneous interaction with lecturers. Although online learning signified promising advances in technology, such platforms may limit engagement between them. Academics need to constantly remind and prompt their students to participate in online discussions and quizzes. As academics, it is important to engage in interactions with students to plan their learning activities, assist in carrying out self-assessments and increase their confidence in solving problems [10] as research has documented that interaction between students and academics as well as university's provision of emotional and social support are essential components for effective learning [11]. Certainly, academics who demonstrate a genuine personal and academic interest in students report stronger student outcomes [12], while regular two-way feedback can enhance self-efficacy and motivation [13].

Findings from the academics' responses highlighted similar sentiments to the students that online learning modalities were an effective source of teaching and learning, with half of all academics learning 'new teaching techniques' and 'becoming creative and innovative'. With the university closure, modifications to clinical skills teaching and placements had to be made, where student placements in clinical settings was forced to cease as a crucial move to allow clinicians to focus on managing patients affected by the pandemic and limit exposure of students to health risks in hospitals. This was a 
disadvantage for students as patient contact is necessary for their learning and assessment. In a London-based medical school, face-to-face lectures and clinical-based teaching during the pandemic were substituted by giving medical students access to an online repository of patient interview recordings and cases with tele-teaching technologies [14]. Such a modality would demand great efforts in interactions from both students and academics and if compromised, this may result in a decrease in quantity and quality of the discussions [15]. In other areas of skills and practicum teaching, academics utilized simulated patients for patient care sessions, and shared recorded videos or links of laboratory and clinical skills teaching to students in place of on-site teaching. Despite such efforts, our findings demonstrated academics' concerns that students' practical skills may have been compromised. Academics may also have limited confidence in transitioning to online clinical teaching as well as a limited experience in interactive methods using digital technologies; hence they feel uncertain about students' achievement of learning outcomes.

Like other universities worldwide, abrupt transitions to the assessments of students had to be made in midst of the pandemic. Assessments were also converted to online methods, making use of online learning management systems for written assignments, oral presentations and vivas. Half of the academics from our study reported positively that this transition allowed them to 'explore all options', therefore 'becoming innovative and creative'. The flexibility to explore options of online examinations, including the opportunity to become more innovative in their approaches, was viewed as a positive but steep learning curve for them. Academics were also prepared for the online mode of examinations through a series of workshops to familiarize themselves with the learning management system and to learn various modalities offered for question setting, and marking or grading strategies. However, academics also reported that 'it was difficult to maintain appropriate and ensure fair assessments' while a majority of students 'felt uncertain about their assessments'. During this transition, there was a need to reduce the width and depth of assessments in response to the premature exclusion of some learning objectives due to the pandemic. Clinical assessments had to be substituted with online viva describing the skills in absence of models, patients, instruments or simulation. Academics were also concerned about achieving fair assessments where exams were proctored online, giving rise to a potential compromise in academic integrity. Another concern raised was loss of internet connectivity during the online examinations leading to a period of non-invigilation of the student as well as whether duration was appropriately allocated to attempt the examinations through this online proctoring. Despite mock tests and dry runs, academics had to prepare to allow more time to compensate for such potential issues.

The British Medical Association [16] published a document outlining a set of principles in education of medical students during COVID-19, which was set to ensure their fair assessment and progression, and to consider reasonable adjustments for students with poor access to internet or computer and at disadvantaged locations (i.e. in rural areas) as well as test securities. In the UK, medical schools have been advised to make alternative arrangements to reschedule their exams in a timely manner and to utilize a variety of resources for teaching and assessments. Provision of facilities and computers as well as a clear policy on appeals such as when assessment had to be terminated due to a technical failure, were drawn up. Other universities may employ different approaches such as canceling or rescheduling 
exams, using modified format exams (online or onsite segregated groups) and using "expert" provided grades.

Physical and Mental Health Impact of Online Education on Students and Academics

The global outbreak of COVID-19 resulted in closures of sports complexes and venues, limiting active participation in sports activities subjecting individuals to be less physically active with more screen time, and consuming unhealthy diets, which may lead to a health issue. Student respondents in our study reported 'missing eating outside' and 'a lack of participation in extracurricular activities', with 'more back problems' and 'eye strain/dry eyes'. Meanwhile, more than half of the academics reported having 'more time for exercise' although they had 'more screen time' leading to 'computer related physical stress' such as back problems, dry eyes or strains and carpal tunnel syndrome.

These findings concur with the social distancing measures implemented in Brunei Darussalam during the pandemic, where food premises were not allowed to provide dine-in services. University events and extracurricular activities were also canceled during the study period. The increased need of computers or devices for online learning led to physical effects as noted in our study, such as back problems, eye strain, dry eyes, computer-related physical stress, most likely to be exacerbated with prolonged screen time.

In an online survey looking into exercise and social behaviors conducted by University College London in $2020,85 \%$ of survey respondents did not engage in any moderate or strenuous exercise while $40 \%$ did not do any gentle exercise such as going for a walk [17]. This was especially seen in the respondents in that survey of ages 18-30 years, where 4 out of 5 did not engage in any moderate or strenuous exercise. The same survey reported that respondents aged above 30 years old were more engaged in gentle activity and concerned about their health in view of their higher risk of lifestyle diseases. In Brunei Darussalam, the government did not impose any lockdown control thus allowing the population to engage in outdoor activities and exercise within a socially acceptable and controlled manner, with the exception of group sports and gatherings. This may be the likely explanation concerning the academics in our study who may have greater self-awareness and responsibility of health issues and hence the need to be physically active at home through exercises or housework. While online exercise resources such as physical strength training may be more feasible and satisfied to older participants, younger people may prefer participation in social or group sports, which at that time, had been restricted. Such findings are consistent with reports that a reduction in physical activity and increase in screen time during the pandemic negatively impacted individual's physical and mental health [18].

Social distancing following school closures may increase mental health problems in adolescents at a time when they are experiencing anxiety over the pandemic, which may be worsened by the absence of interpersonal communication [5], concerns on future employment [4] and lack of understanding of the virus transmission in addition to fearing the unknown. In our study, students identified the feelings of stress, anxiety, loneliness and depression as the mental health effects of the pandemic. Students may experience stress due to increased pressure to perform independent learning and abandoning their usual 
routines, which can lead to psychological consequences such as anxiety, depression, difficulty sleeping and stress eating [20]. As clinical placements had to be cancelled, this could exacerbate students' loneliness, in addition to setting apart from their usual social contacts in schools or colleges [19]. Such findings seen in our study are not dissimilar to other studies. A study in China reported that university students showed higher anxiety levels as students faced the new term with fully online learning [4] while French university students experienced anxiety and stress during social isolation [21]. Anxiety and stress have been observed to affect learning skills such as time management, concentration, study motivation and learning methods and which can affect students' performance [22] and potentially poor academic progression [7].

Similarly, mental health impacts were also observed among academics where almost half of them in our study reported 'feeling more stressed' due to meeting deadlines and unexpected distractions. Concerns related to work, family and self may have also compromised mental health. On the other hand, our findings reported that academics felt a closer relationship with their families. Interestingly, when compared to students, academics experienced less stress, anxiety and loneliness. Our findings can be compared to a study in Spain where university staff reported lower scores of depression, anxiety and stress using the DASS-21 tool compared with students [23]. As the older working community has been working professionally under stressful conditions and able to adjust with work protocols and changes, they may be better tolerant in handling stress better than students, who make up a vulnerable group of adolescents. Being closer to family and gaining their support at home also plays an important role to alleviate stressors amongst the academics.

\section{Conclusion}

The COVID-19 pandemic has brought many changes to academia, where online teaching and learning became mandatory and no longer an option for academics leading to a new norm that had to be swiftly embraced. The pandemic has made the university to realize the importance and necessity of digital technology to deliver teaching. While the initial shift proved to be challenging for students, academics and the administration, it was perceived positively as an innovative move and an investment towards digital technology. Our findings highlighted the fundamentals of a pedagogical student-centered approach where student ownership in their learning can improve their academic performance, increase motivation and confidence, as well as promote greater awareness of their limitations and ability to manage them.

It is envisaged that key messages from our study can provide clearer directives for the university to enhance greater quality of pedagogical methods using innovative approaches, design appropriate courses and materials, offer flexibility in teaching and assessments while building a digital learning culture amongst the university community, with input from the administration and support staff. We recommend a blended pedagogy approach of physical and online classrooms that may be preferred by both students and academics. In addition, it is important to promote the well-being of the university 
community through the use of appropriate programs and available resources promoting physical and mental health.

\section{Abbreviations}

UBD

Universiti Brunei Darussalam

PAPRSB-IHS

Pengiran Anak Puteri Rashidah Sa'adatul Bolkiah Institute of Health Sciences

\section{Declarations}

Ethics approval and consent to participate:The project was approved by PAPRSB Institute of Health Sciences Research Ethics Committee and University Research Ethics Committee of Universiti Brunei Darussalam (UBD/OAVCR/UREC/Apr2020-01), which included consent for eligible students and academics to participate in the study.

Consent for publication: As per ethics approval given by PAPRSB Institute of Health Sciences Research Ethics Committee and University Research Ethics Committee of Universiti Brunei Darussalam (UBD/OAVCR/UREC/Apr2020-01), consent for publication of the data was given by the committee.

Availability of data and materials. The datasets used and/or analysed during this study is available from the corresponding author on request.

Competing interests. The authors declare no conflicts of interest.

Funding. The authors declare that no funding was provided for the study.

\section{Authors' contributions:}

SD provided the concept and design of study, acted as research manager and coordinator

SD, KAM, HAR and LN conducted data collection

HAR and LN designed research tool, performed statistical data analysis and interpretation

Fl drafted, revised and finalized the manuscript

FI, RA, IZ, SM, RR and SD performed interpretation of data and discussion of findings

SD, KAM, HAR, SM, RR and LN provided revisions to the manuscript

All authors read and approved the final manuscript

Acknowledgements: The authors wish to acknowledge the support of the administration staff of PAPRSB Institute of Health Sciences, Universiti Brunei Darussalam, for their technical assistance in this study and 
for sending an invitation email to recruit participants.

DISCLOSURE STATEMENT: The authors declare no funding sources nor any conflicts of interest arisen from this research.

\section{References}

[1] Wong, J., Chaw L., Koh, W.C., Alikhan M.F., Jamaludin, S.A., Poh, W.W.P. \& Naing L. Epidemiological investigation of the first 135 COVID-19 cases in Brunei: Implications for surveillance, control, and travel restrictions. The American Journal of Tropical Medicine and Hygiene. 2020; 103(4):16081613. doi:org/10.4269/ajtmh.20-0771

[2] Shahrill, M., Petra, M.I., Naing, L., Yacob, J., Santos, J.H. \& Abdul Aziz, A.B.Z. New norms and opportunities from the COVID-19 pandemic crisis in a higher education setting: perspectives from Universiti Brunei Darussalam. International Journal of Educational Management. 2021; Vol: ahead-ofprint. No: ahead-of-print. doi:org/10.1108/IJEM-07-2020-0347

[3] Koh, W.C., Naing, L. \& Wong, J. Estimating the impact of physical distancing measures in containing COVID-19: an empirical analysis. International Journal of Infectious Diseases. 2020; 100:4249. doi:org/10.1016/j.jij.2020.08.026

[4] Wang, C. \& Zhao, H. The impact of COVID-19 on anxiety in Chinese university students. Frontiers in Psychology. 2020; 11:1168. doi:10.3389/fpsyg.2020.01168

[5] Cao, W., Fang, Z., Hou, G., Han, M., Xu, X., Dong, J., \& Zheng, J. The psychological impact of the COVID19 epidemic on college students in China. Psychiatry Research. 2020; 287:12934.

doi:org/10.1016/j.psychres.2020.112934

[6] Zhai, Y. \& Du, X. Addressing collegiate mental health amidst COVID-19 pandemic. Psychiatry Research. 2020; 288:113003. doi:org/10.1016/j.psychres.2020.113003

[7] Grubic, N., Badovinac, S. \& Johri, A.M. Student mental health in the midst of the COVID-19 pandemic: A call for further research and immediate solutions. International Journal of Social Psychiatry. 2020; 66(5):517-518. doi:10.1177/0020764020925108

[8] Bradley, V.M. Learning Management System (LMS) use with online instruction. International Journal of Technology in Education. 2021; 4(1):68-92. doi:10.46328/ijte.36

[9] Lucieer, S.M., Jonker, L., Visscher, C., Rikers, R.M. \& Themmen, A.P. Self-regulated learning and academic performance in medical education. Med Teach. 2016; 38(6):585-93.

doi:10.3109/0142159X.2015.1073240 
[10] Dewi, M., \& Wajdi, M. Distance learning policy during pandemic COVID-19. Journal of Education And Technology. 2021; 4:325-333. doi:10.29062/edu.v4i3.192

[11] Bernard, R., Abrami, P., Borokhovski, E., et.al. A meta-analysis of three types of interaction treatments in distance education. Review of Educational Research. 2009; 79(3):1243-1289. doi:10.3102/0034654309333844

[12] Muthuprasad T., Aiswarya, S., Aditya, K.S., \& Jha, G.K. Students' perception and preference for online education in India during COVID -19 pandemic. 2020. Available at SSRN: https://ssrn.com/abstract=3596056 or http://dx.doi.org/10.2139/ssrn.3596056

[13] Al-Amin, M., Zubayer, A.A., \& Deb, B., \& Hasan, M. Status of tertiary level online class in Bangladesh: students' response on preparedness, participation and classroom activities. Heliyon. 2021; 7(1):e05943. doi:10.1016/j.heliyon.2021.e05943

[14] Mian, A. \& Khan, S. Medical education during pandemics: a UK perspective. BMC Med. 2020; 18:100. doi:10.1186/s12916-020-01577-y

[15] Chinelatto, L.A., Costa, T.R.D., Medeiros, V.M.B., Boog, G.H.P., Hojaij, F.C., Tempski, P.Z. \& Martins, M,A. What you gain and what you lose in COVID-19: Perception of medical students on their education. Clinics (Sao Paulo). 2020; 75:e2133. doi:10.6061/clinics/2020/e2133

[16] British Medical Association. BMA Statement of Expectations: Assessments, teaching and attainment of medical students during COVID-19. 2020. British Medical Association.

bma.org.uk. https://www.bma.org.uk/media/2421/bma-statement-of-medical-school-expectationsduring-covid-19-may-2020.pdf

[17] University College London. COVID-19 Social Study Results. 2020. https://www.covidsocialstudy.org

[18] Xiang, M., Zhang, Z., \& Kuwahara, K. Impact of COVID-19 pandemic on children and adolescents' lifestyle behavior larger than expected. Progress in Cardiovascular Diseases. 2020; S00330620(20)30096-7. doi:10.1016/j.pcad.2020.04.013

[19] Loades, M. E., Chatburn, E., Higson-Sweeney, N., Reynolds, S., Shafran, R., Brigden, A., Linney, C., McManus, M. N., Borwick, C., \& Crawley, E. Rapid Systematic Review: The impact of social isolation and loneliness on the mental health of children and adolescents in the context of COVID-19. Journal of the American Academy of Child \& Adolescent Psychiatry. 2020; 59(11):1218-1239. doi:

10.1016/j.jaac.2020.05.009

[20] Liu, N., Zhang, F., Wei, C., Jia, Y., Shang, Z., Sun, L., Wu, L., Sun, Z., Zhou, Y., Wang, Y., \& Liu, W. Prevalence and predictors of PTSS during COVID-19 outbreak in China hardest-hit areas: Gender differences matter. Psychiatry Research. 2020; 287:112921. doi:10.1016/j.psychres.2020.112921 
[21] Husky, M. M., Kovess-Masfety, V., \& Swendsen, J. D. Stress and anxiety among university students in France during Covid-19 mandatory confinement. Comprehensive Psychiatry. 2020;

102:152191. doi:org/10.1016/j.comppsych.2020.152191

[22] Hyseni Duraku, Z., \& Hoxha, L. The impact of COVID-19 on higher education: A study of interaction among students' mental health, attitudes toward online learning, study skills, and changes in students' life. 2020; Vol. ahead-of-print; No. ahead-of-print.

[23] Odriozola-González, P., Planchuelo-Gómez, Á., Irurtia, M. J., \& de Luis-García, R. Psychological effects of the COVID-19 outbreak and lockdown among students and workers of a Spanish university. Psychiatry Research. 2020; 290: 113108.doi:org/10.1016/j.psychres.2020.113108

\section{Figures}




\section{a) Positive Effects}

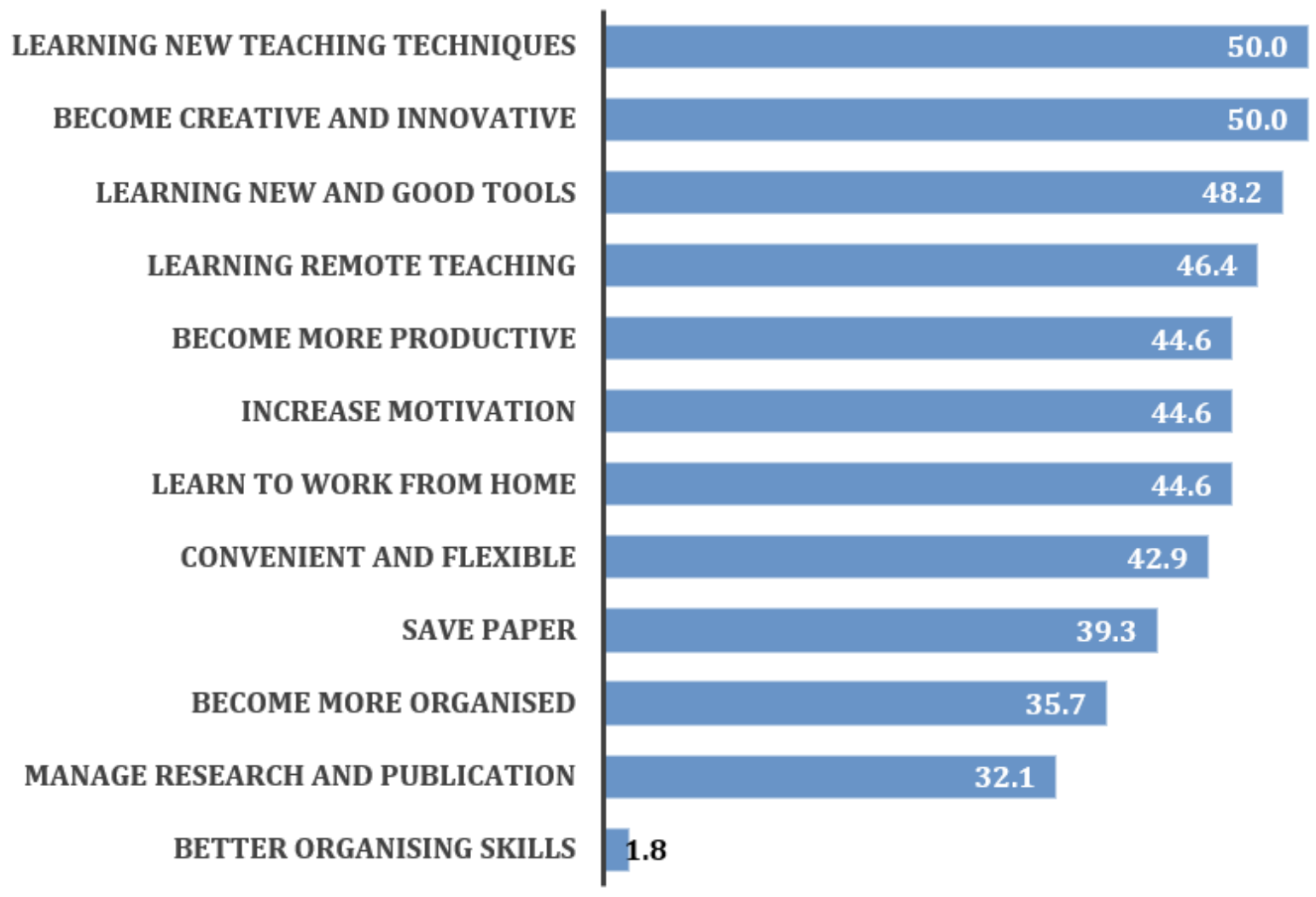

Percentage of respondents

b) Negative Effects

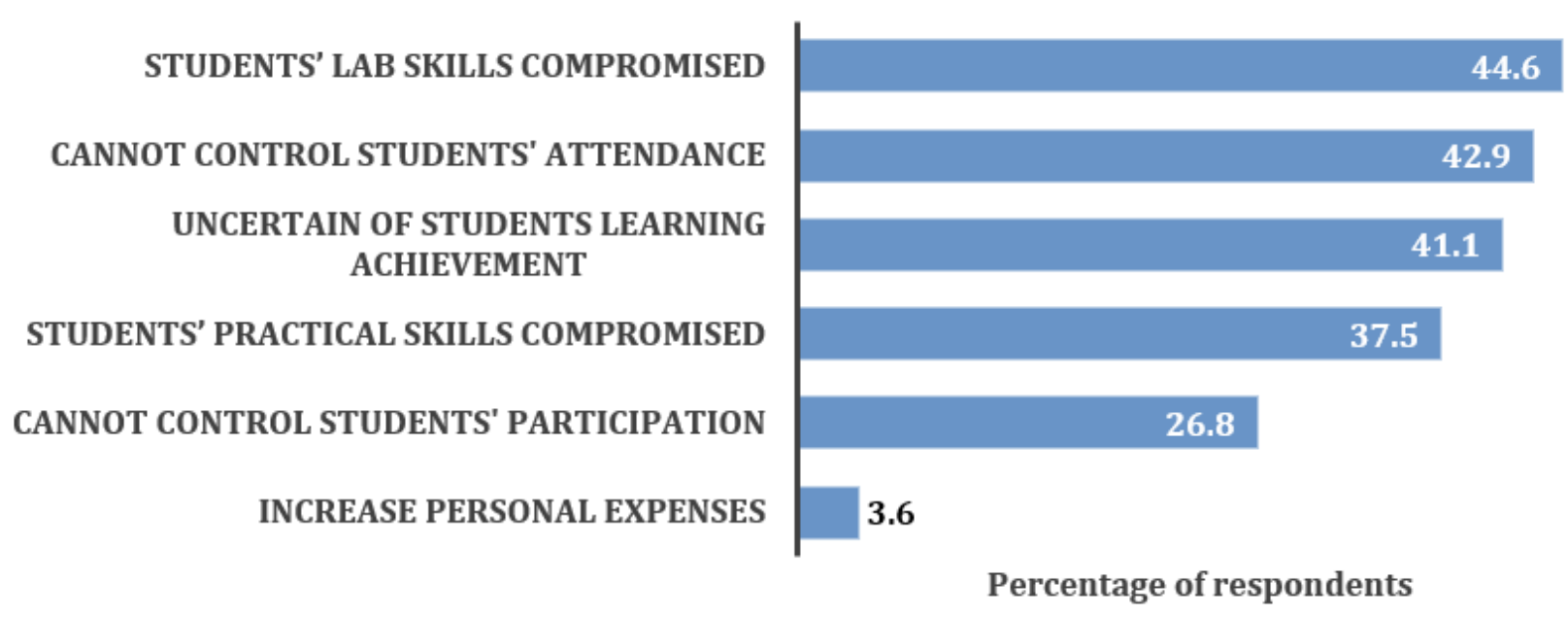

Figure 1

Positive (a) and Negative (b) effects on teaching and research for academics ( $n=56)$ 


\section{(a) Positive effects}

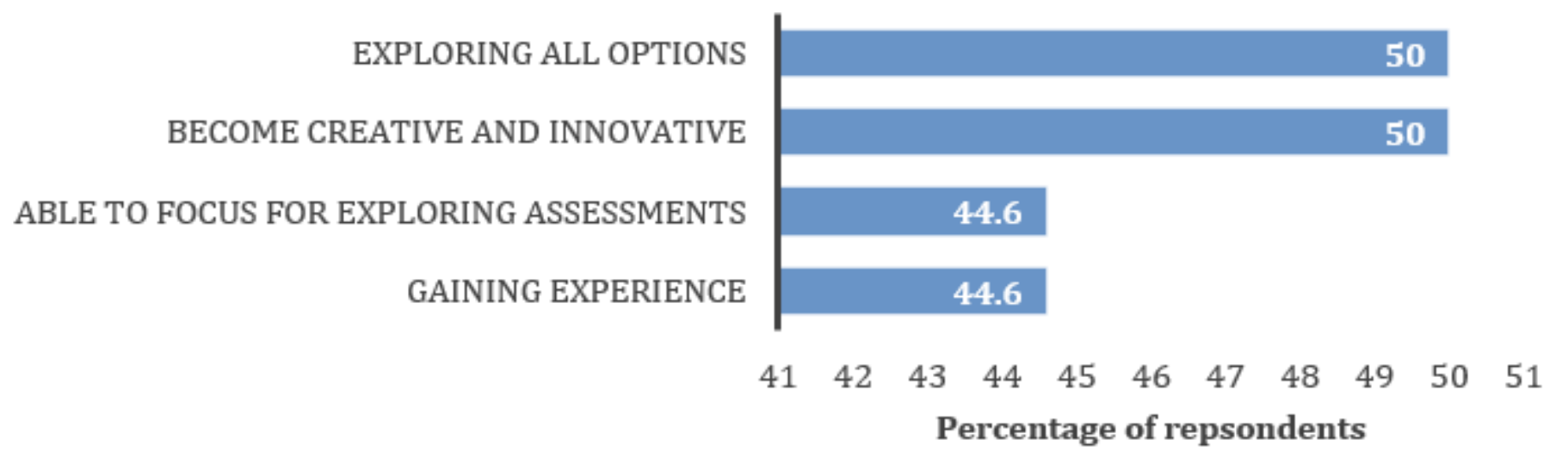

\section{(b) Negative effects}

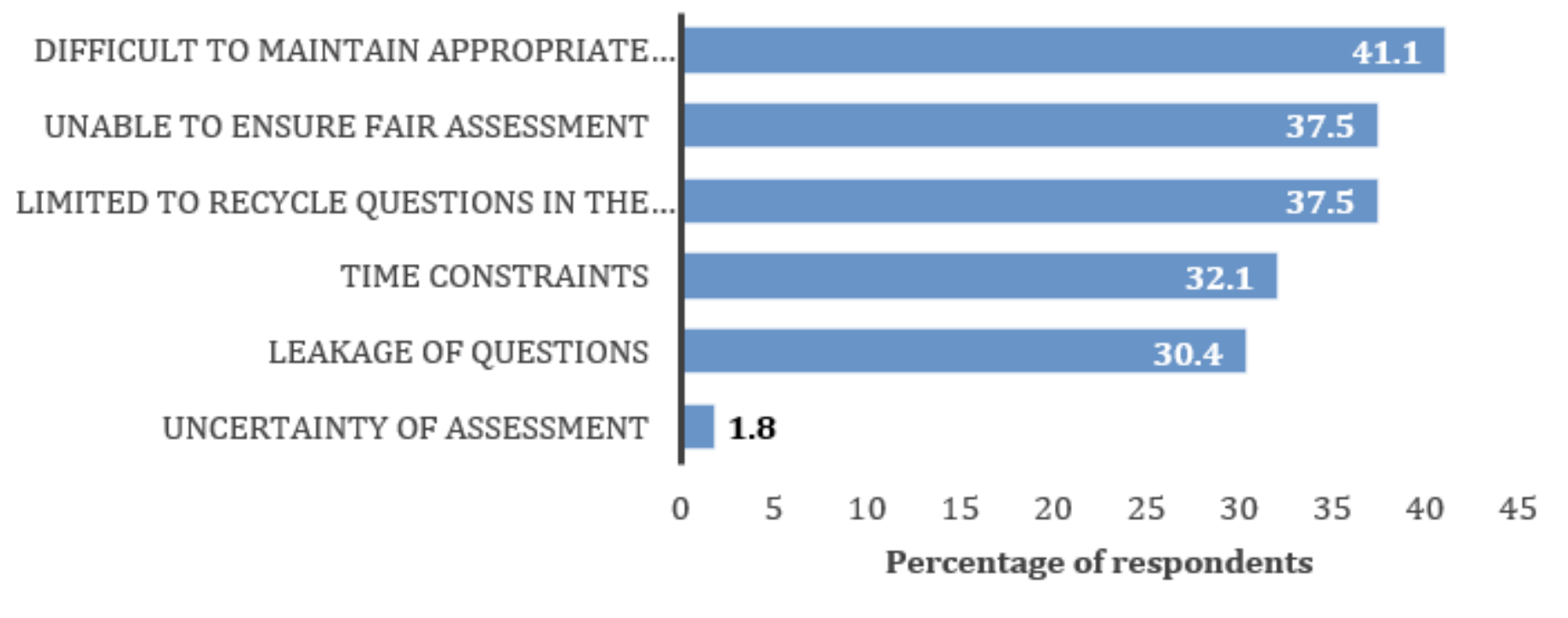

\section{Figure 2}

(a) Positive and (b) Negative effects on academics' designing and giving assessments $(n=56)$ 


\section{(a) Physical health}

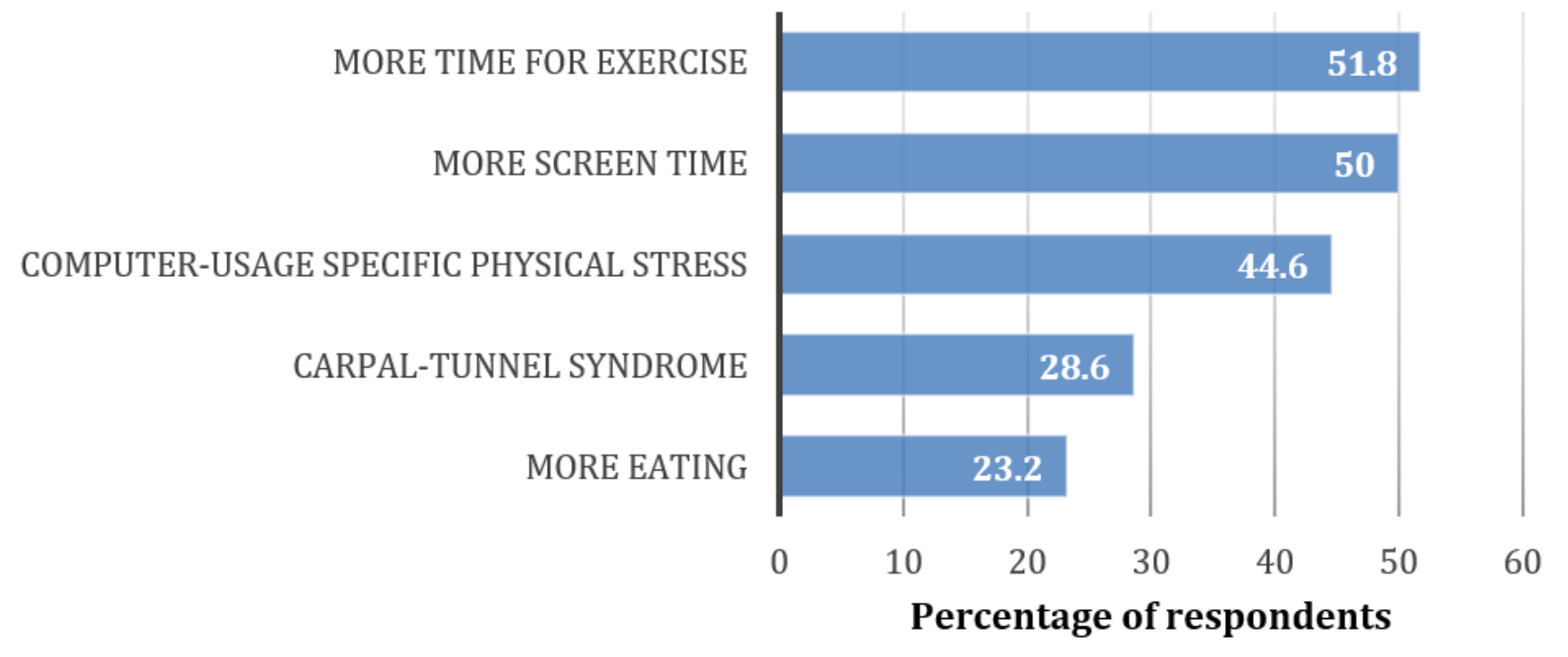

\section{(b) Mental health}

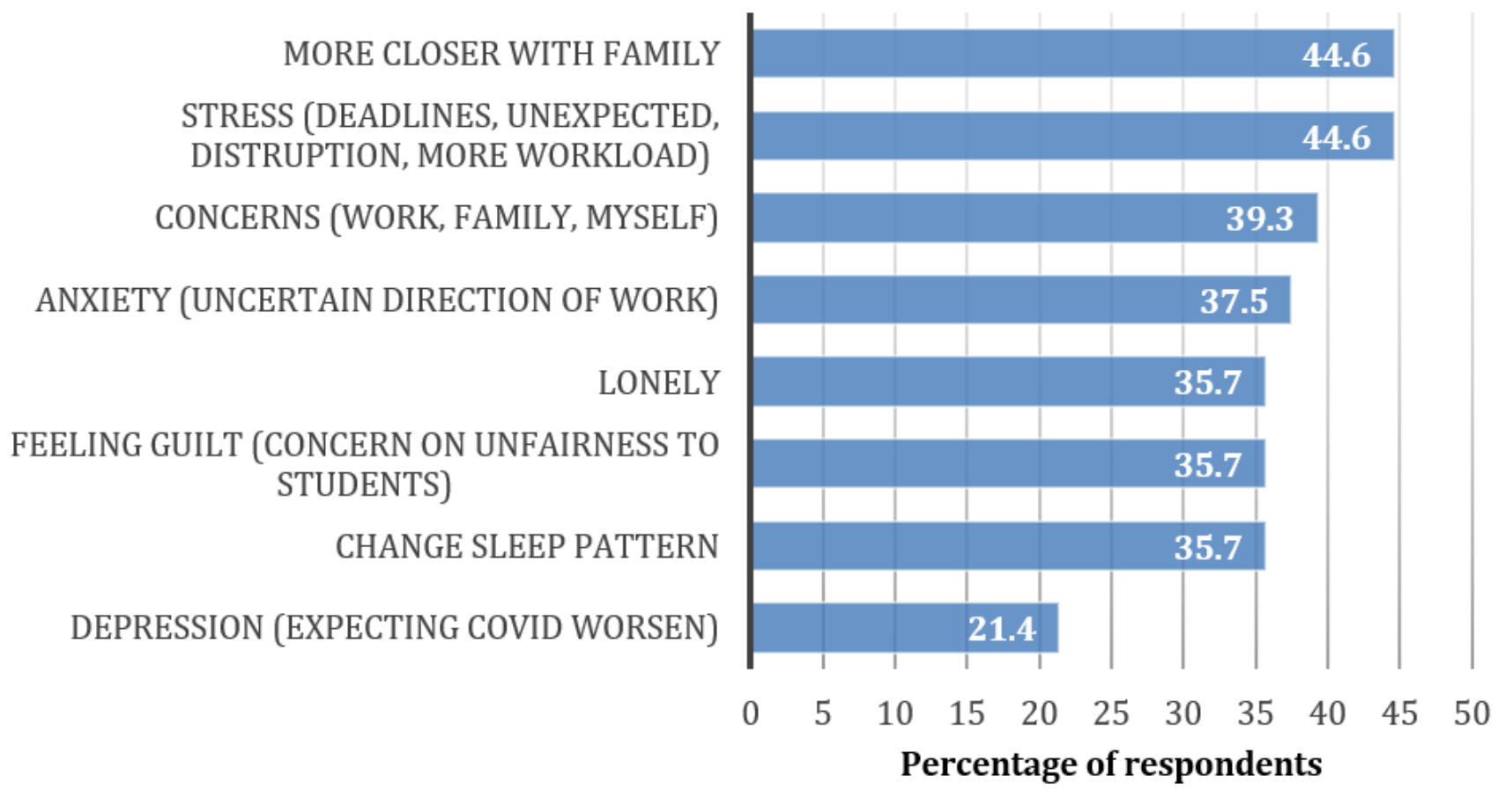

\section{Figure 3}

(a) Physical and (b) Mental health experiences of academics $(n=56)$ 